\title{
A SOLUTION TO 'TOO FEW' WORKING DOWN ON THE FARM - THE HUMAN CAPABILTY IN AGRICULTURE AND HORTICULTURE INITIATIVE
}

\author{
Rupert S Tipples \\ Agriculture and Life Sciences Division \\ Lincoln University
}

\begin{abstract}
This paper describes and analyses how a labour and skills shortage in agriculture (used in the generic and inclusive sense) emerged here in New Zealand towards the end of the twentieth century and how it has been responded to by the industry and government. It delineates a collaborative response to a type of problem affecting many sectors of the New Zealand economy at the present time. A serendipitous conjunction of improved industry economics, productive policy provision, and ministerial and industry will facilitated the creation of a new pan primary industry organisation with the somewhat unwieldy title Human Capability in Agriculture and Horticulture. A picture of what happened has been built up using a range of methodologies (historical - both documentary and oral; case studies; participant observation; and action research) to explain what led to its formation and subsequent progress. Prospects for the future are reviewed with a view to isolating critical features which may be of benefit to other industries experiencing similar labour and skills shortages.
\end{abstract}

"Those who cannot remember the past are condemned to repeat it." George Santayana: The Life of Reason. 1905, Vol.1, ch. 12.

\section{Introduction}

Periodic farm labour crises have been noted across the world at least since the Black Death and the subsequent Ordinance and Statute of Labourers (1349 and 1352). The latter were attempts by the then King of England to freeze wages at their pre-plague levels to prevent the scarcity of labour forcing up wages (Morriss et al., 2001). Governments have regularly moved to counter farm wage rates rising too quickly and the prices of basic foodstuffs becoming too dear. In New Zealand, agricultural labour shortages have occurred several times since 1945. First they were prominent in 1963 at the time of the Agricultural Development Conference. It was believed then that one of the constraints on maximising agricultural exports was a lack of available farm labour. However, the conference concluded that there were no general shortages of permanent farm workers; that there had been substantial increases in farm production and in output per person engaged. Also, at that time there was a satisfactory level of new entrants to farming from school. However, the conference did recommend that all school leavers should receive information about farming and its importance to New Zealand and its employment opportunities. Further, that a national farm training system should be begun, together with research on farm employment and personnel management training for farmers. In addition, there were other recommendations about agricultural statistics because they provided little farm labour data beyond that given by the general Census of Population and Dwellings. Their collection should be improved and they should be released for use more quickly (Tipples and Morriss, 2002a).
In the 1970s farmers only employed labour if it was profitable for them to do so according to Lloyd (1974). In hard economic times they might be stretched for labour but would not necessarily employ more. Then in the early 1980 s attention turned to the rapidly expanding kiwifruit industry and its demands for harvest labour (Martin, 1983). When the industry began to experience economic difficulties the debate curtailed rapidly in favour of the search for greater efficiencies.

Through the Rogernomics era labour shortages were little discussed as farmers went 'cold turkey' from the withdrawal of subsidies. Then through the Employment Contracts era discussion totally ceased. There was continual intensification and the labour force underwent qualitative changes.

The downturn in agricultural fortunes continued during most of the 1990s. Many portrayed agriculture as a sunset industry. Farmers encouraged their children to leave the land and get 'real' qualifications so they could enter other occupations. Many had been dependent on qualified wives (e.g. as nurses or teachers) to bring home a cash income during the years of severe depression, when they themselves had had no alternatives. Then in the mid 1990s dairy farming conditions began to improve and dairy farmers started moving south and buying bigger areas in the South Island and converting them for dairying. These were larger scale farms and needed more employed staff, but staff were hard to find. As economic conditions improved towards 2000 other primary production sectors began to report recruiting problems, which brings us to where this paper's core content commences (Tipples and Morriss, 2002). 
The paper begins by outlining the economic situation of agriculture in the New Zealand economy at the beginning of the new millennium. After that the methodology used in putting the paper together is outlined, before the six threads which led to the initiative being described are traced. Then, how these disparate parts came together is considered, before Human Capability in Agriculture and Horticulture was created. How it chose its programme of projects is subsequently reviewed, before consideration of how those projects have progressed and are likely to progress in the future concludes the paper.

\section{The Significance of Agriculture}

While some may have considered agriculture to be a sunset industry compared to information technology, communications, commerce and tourism, in reality the sector has continued to grow in real dollar terms and in contribution (2003) to export earnings (53\%) and GDP (17\%) (Gardner, 2003). To continue to improve productivity levels and remain competitive internationally the sector needs to co-operate in increasing orchard and farm productivity, in developing higher value products and developing new businesses such as neutraceuticals and pharmaceuticals (ibid.). Such gains will only be obtained with new research and educational developments, new technologies and better on-farm adoption. But these all depend on the people factor. As Gardner puts it "Growth will only come from attracting, retaining and developing the people within the industry and supporting research, education, extension and other services infrastructure" (ibid.). In contrast the industry has had the image of being low skilled with a low propensity to take up new technologies and management practices, together with a strong reliance on family labour, and poor skills in managing staff. With the ageing of the population and greater competition for good people, attraction and retention of the people needed to meet growth and productivity targets will become increasingly severe. Realisation of this conundrum and a serendipitous conjunction of several factors presented an opportunity which industry leaders, politicians, educators and state servants grasped readily. The outcome was Human Capability in Agriculture and Horticulture.

\section{Method}

The study of the creation of Human Capability in Agriculture and Horticulture began long after involvement in the initiative started. It constitutes a case study of current applied research and funding processes. It is an account of how the research-funding nexus has operated since 2000 for an under researched sector of the economy The author had been actively involved in studying the rural labour force since 1977, when he joined the staff at Lincoln College, as it then was. So he was a direct observer of many of the developments described. But as a teacher of 'Labour management', as it was called initially, he was directly involved in trying to improve the standard of management of the rural labour force. That involved teaching, research and extension of the subject and involvement with the former Agricultural Training Council. Beginning from the changing legislative base and then exploring the ramifications of changing 'psychological contracts', particularly among dairy farm staff, he was ideally positioned to make a bid for a research contract tendered on a farm labour topic. It was offered by the Rural Affairs section of the Ministry of Agriculture and Forestry in October 2000. The story is taken from there by a mixture of historical research, by both oral and documentary evidence; by case studies of particular projects; and through an unplanned programme of action research. Action research has been described as starting "... from the idea that research should do more than understand the world, that it should help to change it. It involves a special kind of group decision-making process in which groups of people work together to bring about change, and improve their situation in one way or another. The researcher facilitates the process but doesn't lead it" (Davidson and Tolich, 2001, p. 122).

The author has been concerned throughout to explore the nature of 'labour shortages' and what can be done about them so that agriculture continues to be a significant part of the New Zealand economy.

The formation of Human Capability in Agriculture and Horticulture resulted from a pan industry meeting convened at Rotorua in July 2002. Six threads leading to Rotorua are now outlined beginning with the first in time.

\section{Ministerial Will}

When Jim Sutton became Minister of Agriculture eight months before the end of the Labour Government in 1990 he believed that the role of government in the sector had not been set after the demise of subsidies under Roger Douglas. He then led the promotion of 'sustainability in agriculture' as its primary aim, that was 'sustainable environmentally, sustainable financially, and sustainable socially'. As the Minister has stated recently: "That is still the compass we operate by today" (Smale, 2004).

His policy leanings were heavily influenced by the ravages of Cyclone Bola, which had devastated much of the East Coast of the North Island in 1988. He had proposed overcoming inappropriate land management practices through 'Farm Partnerships - a programme for sustainable land management', because no community could survive the loss of its soils. All the partners in the plan had to contribute to its funding and be active in solving the problems (NZ Farmer, 1990). The National Government of 1990 abandoned the policy, but it became the model for the Sustainable Farming Fund when the Labour-Alliance coalition was returned to power in 1999. Sutton again became Minister of Agriculture and Rural Affairs. Out of office he had seen no help to get good ideas or initiatives off the ground. The Fund was part of the Labour-Alliance commitment to rural communities. "It was the most important measure announced for farming and rural communities in this year's budget", he said (Sutton, 2000). His political 
skills allowed him to secure substantial funding for the Sustainable Farming Fund in the 2000-2001 Budget. \$5million were allocated initially, but funding was planned to increase.

The model established by FARM partnership was continued. The contestable fund was to provide support through "...grants to help in solving community problems thereby enhancing environmental, economic and social outcomes". Three types of practical activities were supported: access to information or knowledge; access to tools for converting that into options and for making informed decisions; and for bringing together communities of interest. Communities wishing to draw on the Fund had to "...express a desire for the aim of the project and be willing to contribute to the project." Commitment to the project was critical, as was financial contribution. The more commitment demonstrated a greater degree of community support. The total government contribution could not exceed 80 percent of the total project cost, but the Fund's administration had to be convinced that the projects offered value-formoney (MAF, 2000).

The value-for-money criterion was quickly tested when some 18 projects were put forward for the Second Round of funding (July 2001) for various projects in the labour/skills area. There seemed to be substantial overlap between projects, which implied duplication of efforts and costs. It was rumoured that $\$ 500,000$ had been allocated to proposed labour projects.

At this point it is necessary to introduce the other threads in the evolving saga.

\section{MeatNZ}

By the end of the 1990s various farming organisations were beginning to note concerns about the difficulties of obtaining staff. MeatNZ, through their farm monitoring programme, became concerned for the pastoral industries and began to develop a strategy for the future around 'people planning'. Their concerns got through to the next 'thread', the policy arm of the Ministry of Agriculture and Forestry.

\section{MAFPol}

MAFPol's involvement in the issue is not surprising. In August 2000 two recently released MAF Policy reports revealed different aspects of rural society. On the one hand the contemporary economic situation was improving, but on the other a gloomy picture of rural New Zealand in the 1990s was presented. A substantial review of 14 research studies carried out for the policy group during the period 1993-1998 revealed increasing stress levels among farmers, with many indicating rural people were near breaking point. Farming was seen as a less desirable occupation. One of the issues highlighted by the studies was the difficulty obtaining farm labour (MAF, 2000). In introducing the review Jim Sutton observed that the research highlighted the success of community initiatives and the significant contribution made by rural people to them (MAF, 2002b)
In June 2000 farmers identified the shortage of skilled labour as one of their major concerns in a further MAF survey (Wharton, 2001). That was shortly followed in October by a call for tenders to investigate what was entitled Skill and Labour Requirement in the Primary Sector from the Ministry's Rural Affairs section.

\section{The Human Capability Framework}

In 1999 quite independently, the Secretary of Labour, John Chetwin, had asked his staff to produce a '...framework for developing policies relating to the development of New Zealand's human capability'. The resulting framework, the Human Capability Framework, appeared just before the General Election. It featured strongly in the Ministerial briefing papers for the incoming Cabinet and went on to provide a research foundation for much policy in the new government (Tipples, 2004). Few realised such a useful tool was available to inform their research and policy proposals.

\section{The Lincoln Connection}

Between the calling for tenders for research project RA 30/2000 Skill and Labour Requirement in the Primary Sector an important event intervened fortuitously. It was the Ninth Labour. Employment and Work Conference held in November 2000. At that conference a research team from Massey University's Labour Dynamics Research Group introduced the Human Capability Framework to the audience, which included the author (Bartley et al., 2001). It immediately fitted with ideas the author had had on the significance of "psychological contracts between individual employers and employees. Upon further reflection it became apparent that it provided an ideal framework for the MAF research contract.

\section{The Massey Connection}

The final thread linking all the threads together was provided by Massey University, in the person of their Director of Agriculture, Stuart Morriss. Stuart had the big advantage that he was already known to the Ministry having worked there in a previous job. He had also had experience of labour issues helping Dexcel to work out a manpower plan for dairy farming.

Massey and Lincoln both submitted tenders. The Massey tender became the head contract, but MAF requested Massey to include Lincoln and the author. The Human Capability Framework (HCF) became the framework around which the research project was based, with Massey analysing the development of agriculture's capacity (the supply side of the farm labour market), while Lincoln investigated the changing pattern of opportunities in the sector (the demand side). These two were then brought together as matching of evolving capacity and opportunity (Morriss et al., 2001).

The research ran from January to June 2001 and the report was delivered in August 2001. A post submission review took place in Wellington on 12 September 2001 and then nothing happened. Subsequently it became 
known that the sponsor of the project had been seconded to the Minister's office. Clearly the research had lost its promoter.

\section{AIRAANZ, Queenstown, 2002}

By December 2001, the author of this paper was becoming frustrated by the inaction, when he knew the data obtained was losing its usefulness with every day that passed. A paper for the Queenstown AIRAANZ conference was needed and the Skill and Labour Requirement in the Primary Sector Report provided the ideal material. Consequently, it reappeared in condensed form as 'The Farm Labour Crisis' (Tipples and Morriss, 2002a and b).

After presentation at Queenstown nothing happened again and the author's frustration increased further... A research assistant suggested sending the paper to Dr Rob Pringle, the CEO of Dexcel, the main organisation responsible for research and extension for dairy farming. His photo had appeared in the Dairy Exporter for January 2002 (p.52) alongside the caption 'Addressing labour availability shortage', which was described as the most important issue facing the dairy industry over the next ten years. In a covering email a suggestion was made to convene a symposium at Lincoln University of researchers involved with the labour issue. The aim of the proposed symposium was to develop a future research strategy on labour and employment issues. Assistance with the implied expenditure was also suggested.

Dexcel claimed to have no unallocated funds. Consequently an approach was made to AGMARDT, another funder of research, meetings and scholarly endeavour for agriculture. Dr Pringle was asked to act as a referee for the application, as an interested but apparently impecunious party. He endorsed the idea of a symposium, but withheld his support from the actual proposal because MAF, through its Sustainable Farming Fund, he advised, was going to organise an industry wide pastoral workshop. His preference was to support MAF rather than Lincoln. It was the first known of the MAF proposal. At this point the threads were beginning to come together, as known interested parties were circulated with the Lincoln symposium proposal. However, the sphere of action had moved from the researcher level to that of senior executives. One other organisation entered the account at this point, AgResearch. Two of its social researchers were part of the group sent the proposed symposium details. Their senior manager responded advising that Dexcel and AgResearch had an initiative planned to address exactly the same issue. Suddenly several parties seemed to be interested in gaining access to the Sustainable Farming Fund's $\$ 1 / 2$ million and they were all centred on Hamilton!

\section{Planning For Rotorua}

The approaches to Dexcel and AGMARDT stirred questions at Lincoln which reached the Vice Chancellor. What was going on? Why was the issue being stirred up? A meeting with the VC ensued at which the author's research on the topic and interest in finding solutions to problems of labour supply were discussed. The funds supposedly available from the Sustainable Farming Fund were also noted. The VC agreed to contact the head of the Sustainable Farming Fund. He had previously been a senior manager with MAF and was happy to use his networks to help secure some funding for Lincoln.

At this point Dexcel and AgResearch became the driving force behind the move to have an industry workshop on the 'labour issue', but working co-operatively with Lincoln. Kevin Steele, Head of MAF's Sustainable Farming Fund, had made it clear that he was not interested in lots of little projects but an overall programme. A critical meeting took place in Wellington on 22 March 2002, which involved Kevin Steele and Godfrey Gloyn (MAF), Phil McLeish (Dexcel), Neels Botha (AgResearch) and Sam McIvor (MeatNZ). As a result of the meeting AgResearch were to write a proposal document to permit funding of the workshop. MeatNZ, Dexcel and Agresearch became equal cofunders of the programme. SFF agreed to cover the cost of the workshop out of an administrative allocation because the proposers were doing their work for him. That would leave the $\$ 1 / 2$ million allocated to labour related projects for research and extension work. Kevin Steele, as the funder of the workshop, set the following objectives for it:

- Review of all activities - current and proposed

- Framework of what is needed

- Needs assessed against activities for gaps and overlaps, together with priorities

- A method of referencing a central group to manage labour initiatives

- A method for calling for expressions of interest/proposals that fit the framework.

They would give him a solid platform or releasing the money. However, he insisted that the structure was not.

So the vital ground work for the Rotorua meeting was in place just five weeks after the initial contact with Dr Pringle. The objectives of the Primary Industry Labour Workshop were refined by $\mathrm{AgResearch}$ as follows:

1. To take stock of current (and where possible past) research and activities in the on-farm pastoral and horticultural "Work in Agriculture" domain.

2. To identify and prioritise knowledge and other gaps in this domain.

3. To identify a strategic approach and initial action plan to address the situation (how industries would work together to face up to the challenge).

4. To look at different funding options.

5. To identify appropriate and willing collaborators. 


\section{Human Resources In Agriculture - An Approach To Identifying A Collective Way Forward: The Rotorua Workshop}

The workshop was considered a key first step in focusing efforts to improve the human resource side of agriculture. It was to take advantage of synergies resulting from working and sharing together by linking a range of people from within the industries, whether industry representatives, government officials, researchers or people representing particular initiatives (MAF, 2002b). As part of the mix MAF always had the aim of establishing a work programme directed by an 'industry based steering group', which would identify priorities and work areas and oversee the detailed work contracted (MAF, 2002c).

Investments resulting were to be targeted at making a real difference.

The final working objectives of the Workshop were:

- To define the 'problem' in the various primary industry sectors

- To 'take stock' of current (and where possible past) research and activities in the on-farm pastoral and horticultural 'Work in Agriculture' domain. This would form the basis of a literature review to be completed as a contract following the Workshop.

- To identify and prioritise knowledge and other gaps in this domain.

Table 1. The Outcome Framework (Gardner, 2003)
- Identify what initiatives needed to be started immediately as well as identify what actions needed taking as part of developing an ongoing strategic approach.

The workshop's focus was kept to 'on-farm human resources and those services directly related to them', such as providers of research and education/training. Forty strategically positioned people were invited. A combined industry structure was endorsed by participants to help build a cohesive way ahead. The various sectors acknowledged the need to recognise their respective situations in achieving that strategic way forward. One of the benefits of the Workshop was the development of cohesion and links between organisations and individuals both working with and researching the area of human resources in primary industry within New Zealand. Researchers present outlined their relevant research, the drivers for it, the approaches undertaken to address the need, and described the resulting publications. In this way the workshop was introduced to the Human Capability Framework, the approach used by Massey and Lincoln in the foundational Skill and Labour Requirement in the Primary Sector - "People make the difference" study (Morriss et al., 2001).

An outcome framework was adopted to help focus and justify proposed projects. The outcomes identified key areas to be addressed by human capability projects and activities. They were grouped in three categories: Supply, Transformation, and Return (Table 1).

\begin{tabular}{|l|l|l|}
\hline & & DESIRED OUTCOMES \\
\hline \multirow{2}{*}{$\begin{array}{l}\text { SUPPLY } \\
\text { Sufficient number of the right } \\
\text { kind of people choose to and are } \\
\text { available to work in the industry. }\end{array}$} & Perception & $\begin{array}{l}\text { Potential quantity of people with the right characteristics are } \\
\text { attracted and retained in the industry. }\end{array}$ \\
\cline { 2 - 3 } & Barriers & $\begin{array}{l}\text { Sufficient interest and opportunity in, and ability to, enter the } \\
\text { agricultural workforce. }\end{array}$ \\
\cline { 2 - 3 } & Tools & $\begin{array}{l}\text { Recruitment and retention, position/candidate matching tools, } \\
\text { educational and training services. }\end{array}$ \\
\hline $\begin{array}{l}\text { TRANSFORMATION } \\
\text { Human resources are transformed } \\
\text { to meet industry needs. }\end{array}$ & $\begin{array}{l}\text { Infrastructure } \\
\text { Transfer }\end{array}$ & $\begin{array}{l}\text { Sufficient Research, Extension, Education professional service } \\
\text { providers to support industry HR needs and on-farm best } \\
\text { practice development. }\end{array}$ \\
\cline { 2 - 3 } & $\begin{array}{l}\text { The abilities of researchers, developers and extension agents } \\
\text { to develop the required tools and services for farmers and } \\
\text { other service providers in a manner most likely to be adopted. } \\
\text { The Research to Farmer processes are in place and used. }\end{array}$ \\
\cline { 2 - 3 } & Uptake & $\begin{array}{l}\text { The ability and motivation of both employees and employers } \\
\text { to adjust to a sustainable HR environment, including } \\
\text { employee management skills and on-farm practices. }\end{array}$ \\
\hline $\begin{array}{l}\text { RETURN } \\
\text { Financial and human resources } \\
\text { allocated for best sustainable } \\
\text { returns. }\end{array}$ & $\begin{array}{l}\text { Sustainable } \\
\text { Returns }\end{array}$ & $\begin{array}{l}\text { Reflect on the adequacy of our investments in infrastructure } \\
\text { and operations in terms of the overall impact this investment } \\
\text { is making to industry. }\end{array}$ \\
\hline
\end{tabular}

The mapping process found:

- There was a high degree of interest in re-using other sector projects and deliverables.

- Duplicated projects should be rationalised, where possible, to free up resources for other investments.
- The gaps highlighted in meeting outcomes pointed to further needed investments.

- No sector was confident what was proposed would have big enough effects to meet the magnitude of change needed. 
A list of 14 discrete projects was identified for the new body and for investment as money allowed. Subsequently $\$ 274,000$ was allocated to 5 projects on Careers Promotion, Forecasting 1, Careers and Training Pathways, Research Stocktake and Non Research Stocktake. A further $\$ 120,000$ was committed to the three projects in the second tier: HR Tool Kit, Stocktake II, and Measuring and Monitoring.

\section{Human Capability in Agriculture And Horticulture}

By the time the new Governance Group, resulting from the Workshop, approved the new Human Capability Strategy in Agriculture and Horticulture a subtle change had overtaken the new body. It started changing its name. Looking back this seems quite a hap hazard process, with different dates of adoption by different spokesmen and groups. From 25 February 2003, when the new Strategy was adopted, the parent body seems to be called Human Capability in Agriculture and Horticulture. However, the Working Group was still describing itself as having 'HR in Agriculture' meetings on 25 June and 7 July 2003, but by the Governance Group meeting of 2 September 2003 it was described as the Human Capabilities in AgHort Working Group (Human Capabilities in AgHort, 2003).

The new title had the great benefit of getting away from the 'thingness' of labour as human resources - perhaps better than farming labour units but not much! The new title recognised that the industry operated with more than inanimate resources, rather with thinking, feeling, believing, and perceiving people. However, it was very unwieldy title. In spite of that the title lasted well into 2004, when a new 'brand' was commissioned: Prospera.

\section{Achievements}

By mid-2004 the first batch of projects was nearly ready. Careers Promotion was into its second year. The Research Stocktakes, which included Australian and New Zealand components, were well on the way to completion. The Non Research Stocktake was undergoing final editing, and the first part of the Forecasting project had been completed. Besides these obvious achievements, several other benefits were claimed for Human Capability in Agriculture and Horticulture. These less obvious benefits included an increased awareness of primary industry human capability issues and associated initiatives; the provision of information from the Stocktakes not previously available; a sharing of experiences between industries; and a building on other industries strengths. Other factors included the benefit of the strategy established influencing the investment decisions of organisations well beyond the original work plan. Closer links had been established too between the AgITO and the HortITO.

When the Department of Labour started producing Industry Profiles at the end of 2003, as part of its Skills Action Plans, Agriculture was the first (DoL, 2003). and was considerably more substantial than the other two to be produced on Tourism and the Wood Processing sector.
That difference may be attributed in part to the extensive comment the Industry Profile contained about the human capability strategy the sector had adopted with the assistance, facilitation and funding derived from the Sustainable Farming Fund and the Ministry of Agriculture and Forestry.

The Industry Profile also drew attention to the role of Industry Partnership. The Agriculture/Horticulture sector was fortunate with the number of 'industry good' organisations that were taking the lead in human capability issues. These bodies were funded through commodity levies under the Commodity Levies Act 1990. Such funds could be, and were, used for issues connected with the sector's labour and skills needs. They were important partners in formulating the industry's human capability strategy (DoL, 2003, p.9).

\section{Reflections}

In the Introduction to this paper the labour difficulties experienced in the early 1960s were recalled, together with the response of the period, the Agricultural Development Conference of 1963-4. At that time many similar initiatives were put in place by a wide range of representatives of the industry (analysis of labour and skills gaps, provision of the Agricultural Training Council, collection of farm labour statistics on an annual basis etc), only for most of them to be undone in the years of excessive cost cutting (Rogernomics and after). Now forty years later the ravages of the 'free' market years are having to be repaired by a new generation. Hopefully our successors will learn the lesson of Santayana (1905).

\section{Lessons Learned}

Participation in the processes described has been the cause for some reflection, from a base at Lincoln, on the personal lessons learned. They may be of benefit to other researchers from the more distant parts of New Zealand from the capital.

First, after the years of the competitive model for public action it is good to see the co-operative model return and work well for rural people. That was clearly facilitated by a long serving Minister of Agriculture, Jim Sutton, who did not let himself become deflected from his aim of achieving sustainable farming. The value of holding a portfolio for a long time should not be forgotten in days when organisational memory is extremely poor.

The unconscious social action research model was essential. The researcher cannot tell the funding agencies what research they should undertake. He or she can only advise what needs to be done and what cannot be done. The governance group has to decide how to invest.

This study shows the value of getting to Wellington on a regular basis and the value of who you know (e.g. networks) and not necessarily what you know, although having a demonstrable track record is indispensable. Personal presence in Wellington to get to meetings permits one to find out what is happening and to be able to 'stake a claim' on an area of personal research 
expertise. The investment in this case paid off for Lincoln University with research contracts resulting to a value of over $\$ 100,000$, a major sum for an area very short of research investment in the past 20 years. Isolation from Wellington is shown to be problematic by the relative success of the Hamilton researchers in the past compared to those at Lincoln for this type of research. Previous Labour, Employment and Work conferences were particularly valuable in this respect. At a personal level LEW 9 and LEW 10 have provided a major conceptual framework, the Human Capability Framework, associated research and publications, and a joint editorship of the New Zealand Journal of Employment Relations.

\section{Future Research}

Understanding and reporting the research process is not a popular form of research, but it is vital to understanding what research gets done and why. Further evaluation of the activity of Human Capability in Agriculture and Horticulture has a place. To see where the co-operative research model leads in years to come is intriguing. The greater emphasis on people and their human capabilities was one of the most exciting changes to observe in the research process reported. Will it continue, or perhaps change in the face of more adverse economic circumstances? Only future research will tell.

\section{References}

Bartley, A., Dupuis, A., and de Bruin, A. (2001) Regional Labour Market Dynamics and Economic Participation: The Mediation Role of Education and Training Institutions. Ninth Conference on Labour, Employment and Work in New Zealand. Institute of Geography, Victoria University of Wellington: 148-155.

Davidson, Carl and Tolich, Martin (2001) Social Science Research in New Zealand - Many Paths to Understanding. Auckland: Longman.

Department of Labour (2003) Industry Profile Agriculture and Horticulture. Found at: http:// www. dol.govt.nz/sap-reports.asp

Gardner, Richard (2003) Human Capability in Agriculture and Horticulture-A Strategy Forward. Primary Industry Management, 6, 4, 3-5.

Human Capabilities in AgHort (2003) Various Meetings' Minutes and other papers. 10 Brandon Street, Wellington.

Lloyd, David W. (1974) A Preliminary Review of Rural Social Conditions With Particular Reference to the Manpower Position on Farms. Report prepared for the Agricultural Production Council, Wellington.

Ministry of Agriculture and Forestry (2000) The Sustainable Farming Fund. Introductory brochure. Wellington.
Ministry of Agriculture and Forestry (2000) The Influence of Social Factors on the Future Performance of the Primary Production Sectors. Wellington.

Ministry of Agriculture and Forestry (2002a) Reports Show Highs and Lows of Rural Sector. Media Release. 28 November.

Ministry of Agriculture and Forestry (2002b) Human Resources in Agriculture. Rotorua Workshop 2224 July 2002. Facilitators' summary found at: http://www.maf.govt.nz/sff/media/humanresources-in-agriculture/summary/summaryhr.htm.

Ministry of Agriculture and Forestry (2002c) Human Resources in Agriculture. Rotorua Workshop 2224 July 2002. Pre - Workshop Notes: Sponsor's Perspective, found at: http://www.maf.govt.nz /sff/media/human-resources-in-agriculture/preworkshop-notes/index.htm.

Morriss, Stuart; Tipples, Rupert,; Townshend, Wendy; McKay, Bruce and Eastwood, Callum (2001) Skill and Labour Requirement in the Primary Sector - "People make the difference" Report prepared for the Ministry of Agriculture and Forestry (RA 30/2000). Massey and Lincoln universities. Available at: http://www.maf.govt.nz /sff/media/human-resources-in-agriculture/others/ index.htm

New Zealand Farmer (1990) Land users warned. 10 October. 112, 40, 2.

Santayana, George (1905) The Life of Reason. Vol.1, Ch. 12.

Smale, Aaron (2004) Timaru cockie reflects on hiss career. Straight Furrow, 21 July, p. 5.

Sutton, Jim (2000) Rural Fund launched. Press release 6 September@: www.beehive.govt.nz

Tipples, Rupert (2004) The Human Capability Framework - An Important and Useful Framework for Understanding the Labour Market? New Zealand Journal of Employment Relations, 29 (1), 3-20.

Tipples, Rupert and Morris, Stuart (2002a) The Farm Labour Crisis - a problem for the new millennium? Celebrating Excellence, Conference of the Association of Industrial Relations Academics of Australia and New Zealand. 6-8 February. Proceedings, Volume 2, 257-266.

Tipples, Rupert and Morris, Stuart (2002b) The Farm Labour Crisis. Primary Industry Management, 5, $4,25-27$.

Wharton, Tony (2001) Identifying the Sector' concerns. Proceedings of the New Zealand Agricultural and Resource Economics Conference. Blenheim, July. 